\title{
Effect of selected Hofmeister salts on textural and rheological properties of nonfat cheese
}

\author{
J. A. Stankey, ${ }^{\star}$ M. E. Johnson, $\dagger$ and J. A. Lucey ${ }^{*} \dagger^{1}$ \\ ${ }^{*}$ Department of Food Science, University of Wisconsin, Madison 53706 \\ †Wisconsin Center for Dairy Research, Madison 53706
}

\begin{abstract}
Three Hofmeister salts (HS; sodium sulfate, sodium thiocyanate, and sodium chloride) were evaluated for their effect on the textural and rheological properties of nonfat cheese. Nonfat cheese, made by direct acidification, were sliced into discs (diameter $=50 \mathrm{~mm}$, thickness $=2 \mathrm{~mm})$ and incubated with agitation (6 $\mathrm{h}$ at $22^{\circ} \mathrm{C}$ ) in $50 \mathrm{~mL}$ of a synthetic Cheddar cheese aqueous phase buffer ( $\mathrm{pH} 5.4$ ). The 3 HS were added at 5 concentrations $(0.1,0.25,0.5,0.75$, and $1.0 \mathrm{M})$ to the buffer. Post-incubation, cheese slices were air dried and equilibrated in air-tight bags for $18 \mathrm{~h}$ at $5^{\circ} \mathrm{C}$ before analysis. Small amplitude oscillatory rheology properties, including the dynamic moduli and loss tangent, were measured during heating from 5 to $85^{\circ} \mathrm{C}$. Hardness was determined by texture profile analysis. Acid-base buffering was performed to observe changes in the indigenous insoluble (colloidal) calcium phosphate (CCP). Moisture content decreased with increasing HS concentration. Cheeses incubated in high concentrations of $\mathrm{SCN}^{-}$softened earlier (i.e., loss tangent $=1$ ) compared with other HS treatments. Higher melting temperature values were observed for cheeses incubated in high concentrations of $\mathrm{SO}_{4}{ }^{2-}$. Hardness decreased in cheeses incubated in buffers with high concentrations of $\mathrm{SCN}^{-}$. The indigenous CCP profile of nonfat cheese was not greatly affected by incubation in $\mathrm{Cl}^{-}$or $\mathrm{SCN}^{-}$, whereas buffers with high concentrations of $\mathrm{SO}_{4}{ }^{2-}$ reduced the acid-base buffering contributed by CCP. The use of high concentrations $(1.0 M)$ of $\mathrm{SCN}^{-}$for incubation of cheeses resulted in a softer protein matrix at high temperatures due to the chaotropic effect of $\mathrm{SCN}^{-}$, which weakened hydrophobic interactions between $\mathrm{CN}$. Cheese samples incubated in $1.0 \mathrm{M}$ $\mathrm{SO}_{4}{ }^{2-}$ buffers exhibited a stiffer protein matrix at high temperatures due to the kosmotropic effect of $\mathrm{SO}_{4}{ }^{2-}$, which helped to strengthen hydrophobic interactions in the proteins during the heating step. This study showed
\end{abstract}

Received August 8, 2010.

Accepted May 16, 2011.

${ }^{1}$ Corresponding author: jalucey@facstaff.wisc.edu that HS influenced the texture and rheology of nonfat cheese probably by altering the strength of hydrophobic interactions between CN.

Key words: Hofmeister series, nonfat cheese, rheology, texture

\section{INTRODUCTION}

The per capita natural cheese consumption in the United States exceeded $14.5 \mathrm{~kg}$ in 2008 (ERS and USDA, 2010). Cheeses, like Cheddar, though marketed as a good source of dietary calcium, are high in fat (e.g., 32\%). The production of reduced- and low-fat varieties has appealed to some health-conscious individuals, yet nonfat (NF) varieties are not very appealing to most consumers. Complete removal of milkfat creates a cheese with numerous defects including pale or translucent color, rubbery texture, dryness, lack of desired flavor, or the presence of off-flavors (Banks, 2004). Fat globules prevent CN proteins from forming a tightly packed network. Removing fat disrupts the fat-protein-moisture ratio within the network, resulting in an increase in both moisture and protein contents. Many methods have been developed to try to produce reduced- and low-fat cheeses but it remains difficult to produce acceptable NF cheese. This research seeks to better understand the protein interactions within the cheese network and how they can be manipulated to alter the textural properties of cheese.

Caseins form the network in cheese, and various types of interactions hold CN micelles together, including hydrophobic interactions, +/- salt bridges, and colloidal calcium phosphate (CCP) crosslinks (Lucey and Fox, 1993; Horne, 1998). These CN interactions can be manipulated by changes in $\mathrm{pH}$, temperature (e.g., heating post-manufacture), and mineral content. Hydrophobic interactions exist as regions of non-polar groups within the CN proteins, shielding themselves from water; moreover water molecules can form hydrogen bonds with the polar regions of $\mathrm{CN}$. Hydrophobic interactions are the main driving force responsible for protein folding. The hydrophobicity of proteins is greatly affected by temperature (e.g., increasing cheese temperature increases hydrophobic interactions), which results in 
the contraction of $\mathrm{CN}$ molecules and a decrease in the overall strength of $\mathrm{CN}$ gel networks (Lucey et al., 2003). The major minerals found within CN micelles are CCP. These mineral nanoclusters form crosslinks that play a major role in the structure and function of the CN micelles; they also contribute to the structural integrity of the CN network in cheese. Solubilization of CCP affects the texture of cheese (Lucey and Fox, 1993). Lowering $\mathrm{pH}$ results in increased solubilization of CCP crosslinks, decreasing the firmness and increasing melt. At very high temperatures, when attractive CN interactions are sufficiently weakened, cheese melts as long as the electrostatic attractions are not too strong (e.g., such as in low-pH cheese; i.e., <5.0) (Lucey et al., 2003). The CN interactions in full-fat cheese networks have been extensively studied (Lucey et al., 2003).

The serum (aqueous) phase may be expressed from cheeses under hydraulic pressure (Morris et al., 1988). The serum phase, although variable among different types of cheeses, manufacture techniques, and with aging, is composed mainly of salts $(\mathrm{Ca}, \mathrm{Na}, \mathrm{P}$, among others) as well as soluble proteins or peptides. The serum phase of cheese can be altered by immersion of cheese in brine or salt buffer solutions that vary in the amount of $\mathrm{NaCl}$ or calcium. O'Mahony et al. (2006) used the buffer immersion approach to alter the mineral content of Cheddar cheese post-manufacture. Increasing the calcium content of cheese post-manufacture decreased melt and increased hardness (O'Mahony et al., 2006). Guinee and Fox (1986) used brine with varying amounts of $\mathrm{NaCl}$ to analyze the movement of salt and water in cheese during the brining process. Increasing the salt content of the brine increased the $\mathrm{NaCl}$ concentration of the cheese, which caused a decrease in the moisture content (Guinee and Fox, 1986).

The Hofmeister salts (HS) are a series of salts classified by their effects on the hydrophobic tendencies of proteins. The Czech scientist, Franz Hofmeister, first studied them in 1888 and is credited for organizing many salts by their effect on egg white gelation (Kunz et al., 2004). These HS influence hydrophobic interactions primarily at high salt concentrations $(>0.2 \mathrm{M})$. At low concentrations of HS, an electrostatic screening effect is observed that is similar for all types of HS. Additions of low concentrations $(\leq 0.2 M)$ of HS (regardless of salt type) screen the charges on protein, which reduces electrostatic interactions between proteins. At high concentrations of HS, charges are already screened and the HS specificity becomes apparent (Zhang and Cremer, 2010). Hofmeister anions have a greater effect on water than cations due to their similar size and charge density as water (Kunz, 2010). Research with HS has primarily focused on protein solubility and the hydrophobic interactions during the gelation of various globular protein systems (Damodaran and Kinsella, 1982; Babajimopoulos et al., 1983; Arntfield et al., 1990; Mulvihill et al., 1990; Bowland and Foegeding, 1995; Lawal, 2006).

The HS appear to interact with water molecules at the surface of proteins (Zhang and Cremer, 2010). The HS anion series can be divided into 2 categories, which historically have been called kosmotropes (ordermaker) that are small, multiply charged ions with a high charge density (e.g., $\mathrm{CO}_{3}{ }^{2-}, \mathrm{SO}_{4}{ }^{2-}, \mathrm{H}_{2} \mathrm{PO}_{4}{ }^{-}$, and $\mathrm{F}^{-}$) and chaotropes (disorder-maker) that are large, singly-charged ions with a low charge density (e.g., $\mathrm{Br}^{-}$, $\mathrm{NO}_{3}^{-}, \mathrm{I}^{-}, \mathrm{ClO}_{4}^{-}$, and $\mathrm{SCN}^{-}$). The historical terms, kosmotrope and chaotrope, are usually not considered very accurate, as recent research indicates that these ions do not have any influence beyond the first hydration shell of proteins (Kunz, 2010).

Chaotropes prefer to interact more strongly with the protein than with the water surrounding the proteins, whereas the kosmotropes interact more strongly with the water surrounding the protein than with the protein itself. Hence, HS disrupt the state (folded or unfolded) of proteins by altering the amount of water on the protein surface, due to the tendency of the salts to interact more with the protein (chaotrope or destabilizing; e.g., $\mathrm{SCN}^{-}$) or with the surface water (kosmotrope or stabilizing, e.g.; $\mathrm{SO}_{4}{ }^{2-}$ ). Lyotropic effects of $\mathrm{Cl}^{-}$have less effect on protein systems, so are often used as a neutral HS when compared with the anions on either end of the HS series (Resch et al., 2005).

It is known that hydrophobic interactions play a key role in the structure of $\mathrm{CN}$ micelles as well as the formation of the CN network in cheese (Horne, 1998; Lucey et al., 2003). We wanted to use salts from the Hofmeister series to probe the importance of hydrophobic interactions in the cheese network. We are not aware of any previous published work in relation to the effect of HS on cheese texture. The objective of this study was to investigate the effects of HS on the textural and rheological properties of NF cheese using a simple model buffer system. Several of the HS are not food grade so a buffer system was considered more appropriate.

\section{MATERIALS AND METHODS}

\section{Synthetic Cheddar Cheese Aqueous Phase Solutions}

Synthetic Cheddar cheese aqueous phase (SCCAP) solutions were prepared according to the method developed by Broome and Limsowtin (2002) and as adapted by O'Mahony et al. (2006). Further modifications were made to reflect the composition of NF cheese base used in this study. The original formulation was based on the serum phase of 1-mo-old Cheddar cheese extracted 
using the hydraulic press method reported by Morris et al. (1988).

The SCCAP solutions were made using the following procedure: disodium hydrogen phosphate $(6.412 \mathrm{~g})$ was dissolved in $700 \mathrm{~mL}$ of deionized water (Milli-Q Reagent Water System; Millipore Corp., Bedford, MA). Citric acid-monohydrate $(2.300 \mathrm{~g})$, sodium chloride $(75.98 \mathrm{~g})$, magnesium sulfate heptahydrate $(0.564 \mathrm{~g})$, magnesium chloride hexahydrate $(3.296 \mathrm{~g})$, potassium chloride $(3.624 \mathrm{~g})$, and sodium acetate trihydrate $(0.600 \mathrm{~g})$ were added in that order. Once the salts were dissolved completely ( $15 \mathrm{~min})$, sodium lactate $(60.056 \mathrm{~g}$ of a $60 \%$ wt/wt syrup) was added. With continuous stirring, 10 $\mathrm{mL}$ of a solution of manganese chloride tetrahydrate $(0.025 \mathrm{~g} / 100 \mathrm{~mL})$ was added. Ca chloride dihydrate was added to bring the Ca concentration of the buffer solution to $2.78 \mathrm{~g} / \mathrm{L}$ because preliminary research on the base cheese demonstrated that at this Ca concentration in the buffer did not alter the insoluble calcium phosphate content in cheese; similar results were reported by O'Mahony et al. (2006). This was followed by $10 \mathrm{~mL}$ of a solution of zinc chloride $(0.625 \mathrm{~g} / 100 \mathrm{~mL})$. The $\mathrm{pH}$ was adjusted to $\mathrm{pH} 5.4$ with hydrochloric acid (0.5 $N)$ and the solution was made up to volume $(1 \mathrm{~L})$ with deionized water. The buffer contained $10 \% \mathrm{NaCl}$. Separate solutions were prepared fresh daily, differing only in the concentration of HS. Three salts from the HS series were used: sodium thiocyanate $\left(\mathrm{SCN}^{-}\right)$, sodium chloride $\left(\mathrm{Cl}^{-}\right)$, and sodium sulfate $\left(\mathrm{SO}_{4}{ }^{2-}\right)$, and these HS were added at 5 different concentrations $(0.1,0.25$, $0.5,0.75$, and $1.0 \mathrm{M}$ ) to the SCCAP solution before the final $\mathrm{pH}$ adjustment. A total of 16 buffers were prepared, differing in their concentrations of HS. All reagents used were of analytical grade (Fisher Scientific, Fair Lawn, NJ).

\section{Nonfat Cheese Base}

Two 9-kg blocks of directly acidified NF cheese were produced by the method described by Brickley et al. (2008) in University of Wisconsin-Madison Babcock Hall Dairy Plant. Citric acid was used to acidify the milk to $\mathrm{pH}$ 5.6. The cheese base had a composition of $57 \%$ moisture, $37 \%$ protein, $4 \%$ ash, and $2 \%$ fat. The blocks were vacuum-packed and were held at approximately $4^{\circ} \mathrm{C}$ for $10 \mathrm{~d}$.

\section{Incubation of Cheese in SCCAP Solutions}

Cheese samples (discs: $50 \times 2 \mathrm{~mm}$ ) were made using a Hobart deli-slicer and were packaged (stacks of 6 separated by parchment paper) and stored frozen $\left(-20^{\circ} \mathrm{C}\right)$ until analysis. Frozen slices were thawed for $2 \mathrm{~d}$ at $4^{\circ} \mathrm{C}$ before use. Samples were wrapped in 1 layer of cheesecloth (to prevent adhesion to the Petri dish surface) and placed in the bottom of a glass Petri dish $(100 \times 20 \mathrm{~mm}) ; 50 \mathrm{~mL}$ of SCCAP solution was added. The Petri dishes were covered with the glass lids to prevent evaporation. Fifteen samples of cheese were incubated at room temperature $\left(22^{\circ} \mathrm{C}\right)$ for $6 \mathrm{~h}$ in the SCCAP solutions for each concentration of salt. Cheeses were also incubated in the control SCCAP solution buffer (i.e., without the extra HS added). The cheese and buffer mixture were continuously agitated on a platform shaker (Lab Line Instruments, Melrose Park, IL) at approximately $15 \mathrm{rpm}$. Following incubation, the samples were removed from the buffer and patted dry to remove excess moisture with a Kimwipe and air dried for $30 \mathrm{~min}$ (inverted after $15 \mathrm{~min}$ ). The samples were stored in plastic bags (Whirl-Pak; Nasco International Inc., Fort Atkinson, WI) and allowed to equilibrate overnight $(18 \mathrm{~h})$ at $4^{\circ} \mathrm{C}$. The following day, samples were analyzed for their compositional, textural, and rheological properties. Post-incubation, the SCCAP solutions were pooled from the Petri dishes and analyzed for their mineral composition.

\section{Analysis of Cheese Composition}

Cheese slices were analyzed before and after incubation for moisture (IDF, 1982), fat (Marshall, 1992), and total protein using the Kjeldahl method (IDF, 1986). Both cheese slices and buffers were analyzed for mineral composition ( $\mathrm{Ca}, \mathrm{P}, \mathrm{Na}$, and $\mathrm{S}$ ) using inductively coupled plasma optical emission spectrometry (Park, 2000). The compositional results of the buffers after incubation were compared with the original buffer formulation. The $\mathrm{pH}$ values were determined by making a slurry ( $4 \mathrm{~g}$ of cheese and $8 \mathrm{~g}$ of deionized water using a mortar and pestle for $2 \mathrm{~min}$ ) and measuring with a $\mathrm{pH}$ probe (pH meter 420A; Orion Research Inc., Beverly, MA). The cheese base was analyzed after $10 \mathrm{~d}$ of storage. The incubated slices were analyzed $1 \mathrm{~d}$ after storage. The acid-base titration method described by Hassan et al. (2004) was used to determine the buffering properties. The buffering due to residual CCP was estimated as the area between the acid and base titrations over the $\mathrm{pH}$ limits 5.2 to 4.1 (Hassan et al., 2004; O'Mahony et al., 2006). Values were normalized using protein content (i.e., buffering area under curve/100 $\mathrm{g}$ of protein) to account for differences in the protein content between cheeses (O'Mahony et al., 2006). All analyses were performed in triplicate.

\section{Determination of Rheological Properties}

Small Deformation Rheological Properties. Small amplitude oscillatory shear (SAOS) properties were measured on a controlled-stress rheometer (Paar 
Physica UDS 200; Physica Messtechnik, Stuttgart, Germany) using a $50-\mathrm{mm}$ serrated parallel plate. Samples (diameter: $50 \mathrm{~mm}$, height: $2 \mathrm{~mm}$ ) were mounted on the peltier (heating) plate, which had been cooled to $5^{\circ} \mathrm{C}$. The samples were loaded based on normal force readings to approximately $1.7 \mathrm{~N}$ and were allowed to relax until a relatively constant $(\sim 1.0 \mathrm{~N})$ force was attained. This method ensured that the plate had proper, uniform contact with the sample during the entirety of the SAOS test. A thin layer of vegetable oil was dispensed around the exposed area of the sample to prevent it from drying out. The sample was heated from 5 to $85^{\circ} \mathrm{C}$ at a constant rate of $1^{\circ} \mathrm{C} / \mathrm{min}$. A frequency of $0.1 \mathrm{~Hz}$ and a strain of $0.5 \%$ (which was within the linear viscoelastic region for our treatments) were used for SAOS tests. The rheological parameters, storage modulus $\left(\mathbf{G}^{\prime}\right)$, loss modulus $\left(\mathbf{G}^{\prime \prime}\right)$, and loss tangent $(\mathbf{L T})$ were measured at 1-min intervals and reported as a function of temperature for each sample. All analyses were performed in triplicate

Large Deformation Rheological Properties. Texture profile analysis was performed using a TA.XT2 Texture Analyzer (Texture Technologies Corp., Scarsdale, NY) using a $35-\mathrm{kg}$ load cell. To prepare samples, 6 incubated cheese slices (diameter: $50 \mathrm{~mm}$, height: 2 $\mathrm{mm}$ ) were stacked on top of each other and stored in a Whirl-Pak bag overnight in the refrigerator $\left(4^{\circ} \mathrm{C}\right.$ for $18 \mathrm{~h}$ ) to allow the stack to fuse together (O'Mahony et al., 2006). Cylindrical samples were obtained using a stainless steel cork borer (i.d.: $13 \mathrm{~mm}$ ) and plugs were extruded using a plunger. Six samples (diameter: 13 $\mathrm{mm}$, height: $12 \mathrm{~mm}$ ) were obtained from each stack and allowed to equilibrate in a sealed plastic bag for $30 \mathrm{~min}$ $\left(\right.$ at $4^{\circ} \mathrm{C}$ ) until tests were performed. The samples were compressed twice to $38 \%$ of their original heights at a rate of $1 \mathrm{~mm} / \mathrm{s}$. Hardness was defined as the maximum height (force) of the first peak (Bourne, 1978). Analyses were performed in triplicate.

\section{Statistical Data Analysis}

Statistical analyses were performed using JMP software (Version 8.0.2; SAS Institute Inc., Cary, NC). Results were analyzed using one-way ANOVA. The level of significant difference was determined at $P<$ 0.05 . When the effects of treatments were statistically significant, the differences between means were analyzed using the Tukey least significant difference test for multiple comparisons of means.

\section{RESULTS}

\section{Composition}

The composition of the control cheese (i.e., cheeses incubated in $10 \% \mathrm{NaCl}$ SCCAP solution without ad- ditional HS) and the cheeses incubated in SCCAP solutions containing $10 \% \mathrm{NaCl}$ and various concentrations of $\mathrm{NaSCN}, \mathrm{NaCl}$, or $\mathrm{Na}_{2} \mathrm{SO}_{4}$ are shown in Figure 1. Another series of SCCAP solutions was made with $3 \%$ $\mathrm{NaCl}$ for various concentrations of $\mathrm{Na}_{2} \mathrm{SO}_{4}$. Cheeses incubated with high concentrations of $\mathrm{SO}_{4}{ }^{2-}$ had significantly lower moisture contents (e.g., $20 \%$ lower than the control) compared with other treatments, therefore making textural comparisons between HS treatments impossible. The use of $3 \% \mathrm{NaCl}$ in the SCCAP solutions resulted in cheese samples incubated with the 1.0 $\mathrm{M} \mathrm{Na}_{2} \mathrm{SO}_{4}$ having comparable moisture contents to cheeses incubated with $1.0 \mathrm{M} \mathrm{Cl}^{-}, \mathrm{SCN}$, and control (Figure 1a). Therefore, the results from the $\mathrm{Na}_{2} \mathrm{SO}_{4}$ treatment in the $3 \% \mathrm{NaCl}$ SCCAP solutions were compared and discussed with the other HS. For comparison purposes, the SCCAP buffer with $10 \% \mathrm{NaCl}$ concentration for $\mathrm{Na}_{2} \mathrm{SO}_{4}$ is also presented in Figures 1 to 5 and in Table 1.

The moisture contents of all of the cheeses incubated in different types of HS decreased with an increasing concentration of salt (Figure 1a). The cheeses incubated in $0.1 \mathrm{M} \mathrm{Cl}^{-}$or $\mathrm{SCN}^{-}$had similar moisture contents to the control. As the concentration of salt increased (from 0.25 to $1.0 \mathrm{M}$ ), cheeses incubated in $\mathrm{Cl}^{-}$or $\mathrm{SCN}^{-}$had significantly lower moisture contents compared with the control, but were not significantly different from each other. At low HS concentrations (0.1 to $0.5 \mathrm{M}$ ), cheeses incubated in $\mathrm{SO}_{4}{ }^{2-}$ (for the $3 \% \mathrm{NaCl}$ buffer) had significantly higher moisture contents than the control or other experimental cheeses. At high HS concentrations $(0.75$ to $1.0 \mathrm{M})$, the cheeses incubated in $\mathrm{SO}_{4}{ }^{2-}(3 \%$ $\mathrm{NaCl}$ buffer) had comparable moisture contents to the cheeses incubated in similar concentrations of $\mathrm{Cl}^{-}$and $\mathrm{SCN}^{-}$salts (Figure 1a). The trends for protein content of cheeses (Figure 1c) varied inversely to those observed for the moisture content (i.e., protein content increased with a decrease in moisture content, as expected).

The $\mathrm{pH}$ values for the cheeses varied depending on the type of HS used for incubation (Figure 1b). Cheeses incubated at different concentrations of $\mathrm{Cl}^{-}$or $\mathrm{SCN}^{-}$ did not significantly differ in $\mathrm{pH}$ from the control. The $\mathrm{pH}$ values of cheeses incubated in all concentrations of $\mathrm{SO}_{4}{ }^{2-}(3 \% \mathrm{NaCl}$ solutions) were significantly higher than the control.

The total calcium content of the cheese samples incubated in HS is shown in Figure 1d. These data were expressed per $100 \mathrm{~g}$ of protein to normalize the differences in protein content between treatments. The calcium content of cheeses incubated in $\mathrm{Cl}^{-}$buffers decreased at high concentrations $(>0.8 M)$ of HS in the SCCAP solution; a concomitant increase occurred in the calcium concentration of these SCCAP buffers. The total calcium content of samples incubated with 

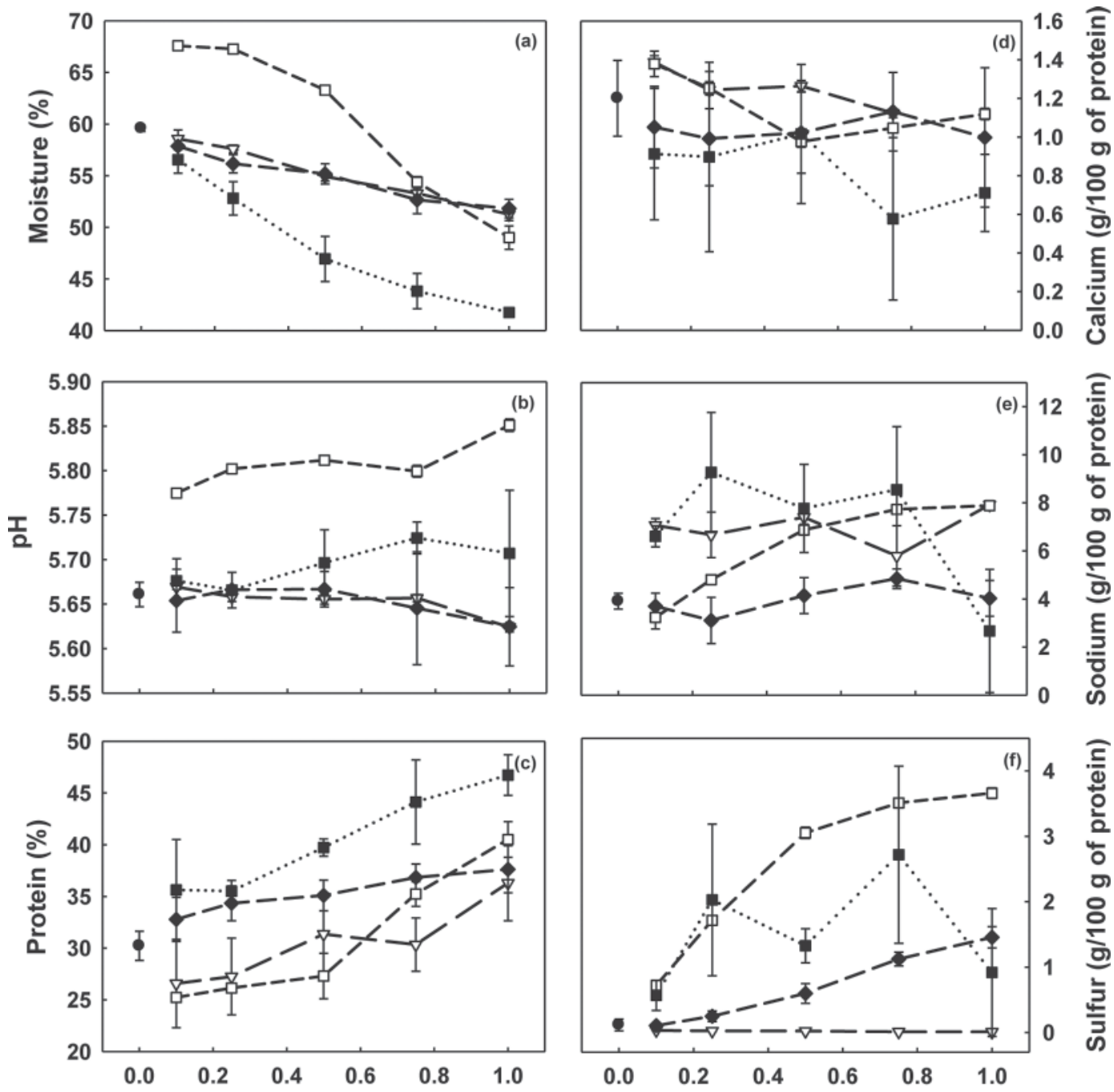

Concentration of Hofmeister Salt Added to SCCAP Solution (M)

Figure 1. The moisture content (a), pH (b), protein (c), calcium (d), sodium (e), and sulfur (f) content of nonfat cheese slices after incubation for $6 \mathrm{~h}$ at $22^{\circ} \mathrm{C}$ in $10 \% \mathrm{NaCl}$ synthetic Cheddar cheese aqueous phase (SCCAP) solutions: control cheese (•), or cheese incubated in different concentrations of $\mathrm{Cl}^{-}(\nabla), \mathrm{SCN}^{-}(\bullet), \mathrm{SO}_{4}{ }^{2-}(\mathbf{\square})$, or an SCCAP solution containing $3 \% \mathrm{NaCl}$ and varying concentrations of $\mathrm{SO}_{4}{ }^{2-}(\square)$. Error bars indicate \pm 1 standard deviation $(\mathrm{n}=3)$.

various concentrations of $\mathrm{SCN}^{-}$or $\mathrm{SO}_{4}{ }^{2-}(3$ or $10 \%$ $\mathrm{NaCl}$ buffers) were not significantly different from the control cheese.

The total sodium content of cheese samples (expressed per $100 \mathrm{~g}$ of protein) incubated with HS is shown in Figure 1e. The sodium content of cheese increased with increasing concentration of $\mathrm{Cl}^{-}$or $\mathrm{SO}_{4}{ }^{2-}(3 \% \mathrm{NaCl})$ in the SCCAP solution; a concomitant decrease occurred in the sodium concentration of the SCCAP buffer (results not shown). This was expected as $\mathrm{Na}^{+}$concentration increased with increasing HS concentration $\left(\mathrm{Na}^{+}\right.$is the counter ion used for the HS series). In buffers with $1.0 \mathrm{M} \mathrm{Cl}^{-}$, the sodium concentration of cheese was twice $(7.92 \mathrm{~g} / 100 \mathrm{~g}$ of protein) that of the control $(3.91 \mathrm{~g} / 100$ $\mathrm{g}$ of protein). The sodium content of cheeses incubated in varying concentrations of $\mathrm{SCN}^{-}$was not significantly different from the control at any HS concentration.

The total sulfur content of the cheese samples incubated with HS is shown in Figure 1f. An increase in sulfur concentration occurred with increasing concentrations of $\mathrm{SCN}^{-}$and $\mathrm{SO}_{4}{ }^{2-}(3 \% \mathrm{NaCl})$ in the SCCAP solution; a concomitant decrease occurred in the sulfur concentration of the SCCAP buffer (results not shown). This trend was expected, as sulfur is present in both $\mathrm{SCN}^{-}$and $\mathrm{SO}_{4}{ }^{2-}$ HS. Cheese samples incubated in SCCAP solutions containing $1.0 \mathrm{M} \mathrm{SCN}^{-}$or $\mathrm{SO}_{4}{ }^{2-}(3 \%$ $\mathrm{NaCl}$ ) had total sulfur concentrations of 1.45 and 3.56 $\mathrm{g} / 100 \mathrm{~g}$ of protein, respectively. No significant change 
Table 1. Small deformation rheological properties of nonfat cheese slices after incubation in synthetic Cheddar cheese aqueous phase (SCCAP) solutions containing $1.0 \mathrm{M}$ concentrations of several Hofmeister salts for $6 \mathrm{~h}$ at $22^{\circ} \mathrm{C}^{1}$

\begin{tabular}{|c|c|c|c|c|c|c|c|c|}
\hline \multirow[b]{2}{*}{ Treatment } & \multicolumn{2}{|c|}{ Storage modulus } & \multicolumn{2}{|c|}{ Loss modulus } & \multicolumn{2}{|c|}{ Loss tangent (LT) } & \multirow{2}{*}{$\begin{array}{c}\mathrm{LT} \text { at } 85^{\circ} \mathrm{C} \\
\left(\mathrm{LT}_{85}\right)\end{array}$} & \multirow{2}{*}{$\begin{array}{c}\text { Temperature } \\
\text { where } \mathrm{LT}=1 \\
\left(\text { Melt }_{\mathrm{T}} ;{ }^{\circ} \mathrm{C}\right)\end{array}$} \\
\hline & $10^{\circ} \mathrm{C}(\mathrm{kPa})$ & $70^{\circ} \mathrm{C}(\mathrm{Pa})$ & $10^{\circ} \mathrm{C}(\mathrm{kPa})$ & $70^{\circ} \mathrm{C}(\mathrm{Pa})$ & $10^{\circ} \mathrm{C}$ & $70^{\circ} \mathrm{C}$ & & \\
\hline$\overline{\text { Control }}$ & $10.2 \pm 2.9^{\mathrm{a}}$ & $485 \pm 1.44^{\mathrm{a}}$ & $10.2 \pm 2.3^{\mathrm{a}}$ & $156 \pm 67^{\mathrm{a}}$ & $0.25 \pm 0.01^{\mathrm{a}}$ & $3.28 \pm 0.52^{\mathrm{ac}}$ & $3.90 \pm 0.51^{\mathrm{a}}$ & $56.6 \pm 1.5^{\mathrm{a}}$ \\
\hline $\mathrm{Cl}^{-}$ & $13.4 \pm 3.6^{\mathrm{a}}$ & $696 \pm 240^{\mathrm{a}}$ & $13.4 \pm 3.6^{\mathrm{ab}}$ & $428 \pm 118^{\mathrm{b}}$ & $0.26 \pm 0.02^{\mathrm{a}}$ & $1.61 \pm 0.11^{\mathrm{b}}$ & $2.28 \pm 0.18^{\mathrm{b}}$ & $67.0 \pm 0.8^{\mathrm{b}}$ \\
\hline $\mathrm{SCN}^{-}$ & $11.5 \pm 4.5^{\mathrm{a}}$ & $228 \pm 42^{\mathrm{b}}$ & $11.5 \pm 4.5^{\mathrm{a}}$ & $59 \pm 16^{\mathrm{c}}$ & $0.37 \pm 0.07^{\mathrm{b}}$ & $3.97 \pm 0.45^{\mathrm{c}}$ & $3.18 \pm 0.24^{\mathrm{c}}$ & $44.1 \pm 0.7^{\mathrm{c}}$ \\
\hline $\mathrm{SO}_{4}^{2-}(3 \% \mathrm{NaCl})$ & $57.7 \pm 38.3^{\mathrm{b}}$ & $863 \pm 327^{\mathrm{a}}$ & $133 \pm 69.6^{\mathrm{bc}}$ & $236 \pm 47^{\mathrm{a}}$ & $0.39 \pm 0.07^{\mathrm{b}}$ & $3.00 \pm 0.15^{\mathrm{a}}$ & $3.63 \pm 0.33^{\mathrm{ac}}$ & $56.8 \pm 0.8^{\mathrm{a}}$ \\
\hline $\mathrm{SO}_{4}^{2-}(10 \% \mathrm{NaCl})$ & $107 \pm 64.8^{\mathrm{b}}$ & $704 \pm 106^{\mathrm{a}}$ & $219 \pm 122.8^{\mathrm{c}}$ & $878 \pm 333^{\mathrm{b}}$ & $0.44 \pm 0.12^{\mathrm{b}}$ & $0.98 \pm 0.03^{\mathrm{d}}$ & $1.31 \pm 0.09^{\mathrm{d}}$ & $75.4 \pm 1.4^{\mathrm{d}}$ \\
\hline
\end{tabular}

${ }^{\mathrm{a}-\mathrm{d}}$ Means within a column with different superscripts differ [Tukey Honestly Significant Difference (HSD); $\left.P<0.05\right]$.

${ }^{1}$ Values are means \pm standard deviation from 3 replicates.

occurred in total sulfur content in the cheeses incubated in buffers with various concentrations of $\mathrm{Cl}^{-}$compared with control cheeses. Cheeses incubated in $1.0 \mathrm{M} \mathrm{SO}_{4}{ }^{2-}$ $(10 \% \mathrm{NaCl})$ had lower sulfur content, although this may have been due to variable composition in this sample due to the greatly decreased moisture content.

\section{Acid-Base Buffering Curves}

The acid-base buffering curves of the cheese samples incubated in SCCAP solutions for the control cheese and cheeses incubated with $1.0 \mathrm{M}$ of the HS are shown in Figure 2. Cheeses incubated in $1.0 \mathrm{M} \mathrm{SO}_{4}{ }^{2-}$ (both 3 and $10 \% \mathrm{NaCl}$ solutions; Figure $2 \mathrm{~d}$,e) produced very different shaped curves when compared with the other treatments. Control, 1.0 $\mathrm{M} \mathrm{Cl}^{-}$, and 1.0 $\mathrm{M} \mathrm{SCN}^{-}$cheese samples had buffering peaks at a $\mathrm{pH}$ of approximately 4.8 on acidification from the initial pH to $\mathrm{pH} 3.0$ (Figure 2a,b,c). The buffering areas due to CCP for cheeses incubated in $1.0 \mathrm{M} \mathrm{Cl}^{-}$and $1.0 \mathrm{M} \mathrm{SCN}^{-}$(Figure 2b,c) were visually larger than the control (Figure 2a). The normalized CCP buffering area of the control cheese (i.e., cheeses incubated in SCCAP solution containing no additional HS) and the cheeses incubated in SCCAP solutions containing $0.1,0.25,0.5,0.75$, or $1.0 \mathrm{M}$ HS are shown in Figure 3. When normalized by protein content, the buffering area due to CCP solubilization for cheeses incubated in $1.0 \mathrm{M} \mathrm{Cl}^{-}$and $\mathrm{SCN}^{-}$solutions were not significantly different from the control (Figure $3)$. The buffering areas for cheeses incubated in all concentrations of $\mathrm{SO}_{4}{ }^{2-}(3 \%$ and $10 \% \mathrm{NaCl}$ solution) were significantly smaller than the control (Figure 3 ). The normalized CCP buffering areas of cheeses incubated in $\mathrm{Cl}^{-}$and $\mathrm{SCN}^{-}$buffers decreased with increasing $\mathrm{HS}$ concentration up to $0.75 \mathrm{M}$, but were still larger than the control (Figure 3).

\section{Rheological Properties}

Small Deformation Rheological Properties. The changes in rheological properties of cheeses during heating from 5 to $85^{\circ} \mathrm{C}$ are shown in Figure 4. Rheological properties are summarized in Table 1. At low temperatures (e.g., $5^{\circ} \mathrm{C}$ ), cheeses incubated in $\mathrm{SO}_{4}{ }^{2-}$ (both 3 and $10 \% \mathrm{NaCl}$ ) solutions had much higher $\mathrm{G}^{\prime}$ values than did the other treatments. At $60^{\circ} \mathrm{C}$, cheeses incubated in the $\mathrm{Cl}^{-}$solution had similar $\mathrm{G}^{\prime}$ values compared with the cheeses incubated in $\mathrm{SO}_{4}{ }^{2-}(3 \%$ $\mathrm{NaCl}$ ) solutions. At temperatures $\geq 60^{\circ} \mathrm{C}$, the $\mathrm{Cl}^{-}$and $\mathrm{SO}_{4}{ }^{2-}(10 \% \mathrm{NaCl}$ buffer$)$ cheeses had higher $\mathrm{G}^{\prime}$ values compared with the other treatments. At $5^{\circ} \mathrm{C}$, the control, $\mathrm{SCN}^{-}$, and $\mathrm{Cl}^{-}$cheeses had similar $\mathrm{G}^{\prime}$ values. At $>10^{\circ} \mathrm{C}$, cheeses incubated in $\mathrm{SCN}^{-}$solutions had significantly lower $\mathrm{G}^{\prime}$ values than did other treatments over the rest of the heating range (Figure 4a).

It should be noted that the moisture content of the cheeses incubated in $1.0 \mathrm{M} \mathrm{SO}_{4}{ }^{2-}(3 \% \mathrm{NaCl}$ solutions $)$, $\mathrm{Cl}^{-}$, or $\mathrm{SCN}^{-}$were similar; however, the cheeses incubated in $\mathrm{SCN}^{-}$solutions had significantly lower $\mathrm{G}^{\prime}$ values at all temperatures compared with the other cheeses.

At temperatures $<50^{\circ} \mathrm{C}$, cheeses incubated in $\mathrm{SO}_{4}{ }^{2-}$ (i.e., both 3 and $10 \% \mathrm{NaCl}$ ) solutions had much higher $\mathrm{G}^{\prime \prime}$ values than did the other treatments (Figure $4 \mathrm{~b}$ ). Cheeses incubated in $\mathrm{SCN}^{-}$and $\mathrm{Cl}^{-}$had higher $\mathrm{G}^{\prime \prime}$ values than did the control at low temperatures $\left(\leq 20^{\circ} \mathrm{C}\right)$. At high temperatures (i.e., $>65^{\circ} \mathrm{C}$ ), control cheeses or cheeses incubated in $\mathrm{SCN}^{-}$had lower $\mathrm{G}^{\prime \prime}$ values than did cheeses incubated in $\mathrm{Cl}^{-}$or $\mathrm{SO}_{4}{ }^{2-}$ solutions.

At low temperatures (i.e., $5-40^{\circ} \mathrm{C}$ ), the $\mathrm{LT}$ values for the different treatments were similar (Figure 4c). The LT values for cheeses incubated in $\mathrm{SCN}^{-}$solutions started to increase at lower temperatures $\left(\sim 35^{\circ} \mathrm{C}\right) \mathrm{com}-$ pared with other treatments. The LT values for the control and $\mathrm{SO}_{4}{ }^{2-}(3 \% \mathrm{NaCl}$ solutions $)$ cheeses only began to increase at $>50^{\circ} \mathrm{C}$. Cheeses incubated in $\mathrm{Cl}^{-}$and $\mathrm{SO}_{4}{ }^{2-}(10 \% \mathrm{NaCl}$ solutions $)$ buffers did not demonstrate an increase in LT until $>60^{\circ} \mathrm{C}$ (Figure 4c).

Cheeses incubated in $1.0 \mathrm{M} \mathrm{SCN}^{-}$exhibit an $\mathrm{LT}_{\max }$ (Figure $4 \mathrm{c})$; at high temperatures $\left(>70^{\circ} \mathrm{C}\right)$ the $\mathrm{G}^{\prime}$ curve began to flatten, whereas $\mathrm{G}^{\prime \prime}$ values continued to decrease. The other treatments did not demonstrate 

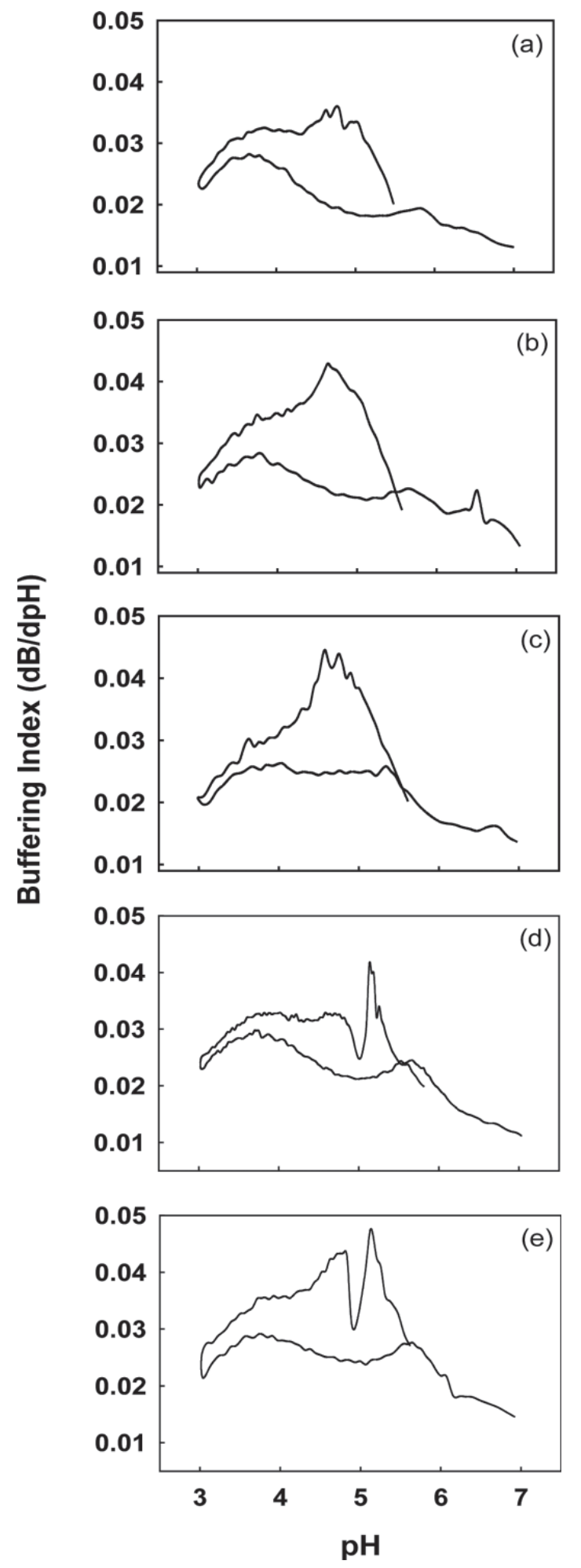

Figure 2. Acid-base buffering curves of nonfat cheese slices after incubation for $6 \mathrm{~h}$ at $22^{\circ} \mathrm{C}$ in a $10 \% \mathrm{NaCl}$ synthetic Cheddar cheese aqueous phase (SCCAP) solution, control (a), or containing $1.0 \mathrm{M} \mathrm{Cl}^{-}$ (b), $\mathrm{SCN}^{-}$(c), $\mathrm{SO}_{4}{ }^{2-}$ (d); or in a $3 \% \mathrm{NaCl}$ SCCAP solution containing 1.0 $\mathrm{M} \mathrm{SO}_{4}{ }^{2-}$ (e). Cheese samples were titrated from their initial $\mathrm{pH}$ to $\mathrm{pH} 3.0$ with $0.5 \mathrm{~N} \mathrm{HCl}$ and then back-titrated to $\mathrm{pH} 7.0$ with $0.5 \mathrm{~N}$ $\mathrm{NaOH}$. Representative curves for each treatment are shown. an $\mathrm{LT}_{\max }$ (at least not at the measured frequency of $0.1 \mathrm{~Hz})$. At $85^{\circ} \mathrm{C}$, the $\mathrm{LT}$ values $\left(\mathrm{LT}_{85}\right)$ for the control and other 1.0 $M$ HS treatments (excluding $\mathrm{SCN}^{-}$) were still increasing (Table 1; Figure 4c). Large $\mathrm{LT}_{85}$ values indicate a high degree of fluidity and rapid relaxation of protein-protein bonds, which facilitates rearrangement within the CN matrix (O'Mahony et al., 2006). The $\mathrm{LT}_{85}$ values for cheeses were in the following order: control $>\mathrm{SO}_{4}{ }^{2-}(3 \% \mathrm{NaCl}$ solution $)>\mathrm{SCN}^{-}>\mathrm{Cl}^{-}>$ $\mathrm{SO}_{4}{ }^{2-}(10 \% \mathrm{NaCl}$ solution).

An $\mathrm{LT}$ value $=1$ (i.e., when the ratio of $\mathrm{G}^{\prime \prime} / \mathrm{G}^{\prime}=$ 1 ) is sometimes (Sutheerawattananonda and Bastian, 1998) considered the melting temperature $\left(\mathbf{M e l t}_{\mathrm{T}}\right)$ of cheese (Table 1). It should be noted that for cheese the temperature where $G^{\prime \prime} / G^{\prime}=1$ depends on the applied frequency (Udayarajan et al., 2005). Cheeses incubated in 1.0 $\mathrm{M} \mathrm{SCN}^{-}$solutions had lower Melt ${ }_{\mathrm{T}}\left(\sim 44^{\circ} \mathrm{C}\right)$ than the other treatments and higher $\mathrm{LT}$ values at $70^{\circ} \mathrm{C}$ than the cheeses incubated in $\mathrm{SO}_{4}{ }^{2-}$ or $\mathrm{Cl}^{-}$solutions. The Melt $_{\mathrm{T}}$ for cheeses were in the following order: $\mathrm{SO}_{4}{ }^{2-}$ $(10 \% \mathrm{NaCl}$ solution $)>\mathrm{Cl}^{-}>\mathrm{SO}_{4}{ }^{2-}(3 \% \mathrm{NaCl})=$ control $>\mathrm{SCN}^{-}$.

Large Deformation Rheological Properties. The large deformation rheological properties of the cheese samples incubated in SCCAP solutions with various types of HS are shown in Figure 5. Hardness increased with an increase in the HS concentration for $\mathrm{Cl}^{-}$and $\mathrm{SO}_{4}{ }^{2-}$. This trend was possibly due to a decrease in moisture content with an increase in HS concentration (Figure 1a). Cheese samples incubated in $1.0 \mathrm{M} \mathrm{Cl}^{-}$or $\mathrm{SO}_{4}{ }^{2-}$ solutions were significantly harder than the control. Cheeses incubated in high concentrations of both $\mathrm{SO}_{4}{ }^{2-}$ treatments were significantly harder than cheeses incubated in $\mathrm{Cl}^{-}$, although under these conditions (i.e., $>0.8 \mathrm{M})$, the $\mathrm{SO}_{4}{ }^{2-}(3 \% \mathrm{NaCl}$ solution $)$ cheese had a similar moisture content to the $\mathrm{Cl}^{-}$cheese (Figure 1a). Cheese samples incubated in solutions with high concentrations of $\mathrm{SCN}^{-}(>0.5 \mathrm{M})$ were significantly softer than the control, although they had lower moisture contents than the control (Figure 1a). Cheeses incubated in low $(\leq 0.5 \mathrm{M}) \mathrm{SO}_{4}{ }^{2-}(3 \% \mathrm{NaCl})$ concentrations were softer than the control cheese probably due to the samples having high moisture contents (Figure 1a).

\section{DISCUSSION}

In this study, the $3 \mathrm{HS}$ demonstrate a significant effect on the compositional, textural, and rheological properties of NF cheese. It is likely that these effects are due to the kosmotropic and chaotropic nature of these HS, especially at high concentrations (e.g., 1.0 M). The dehydration effect of sodium on the cheese matrix (Monib, 1962) also contributes to the observed physical and compositional changes. At low HS concentrations 


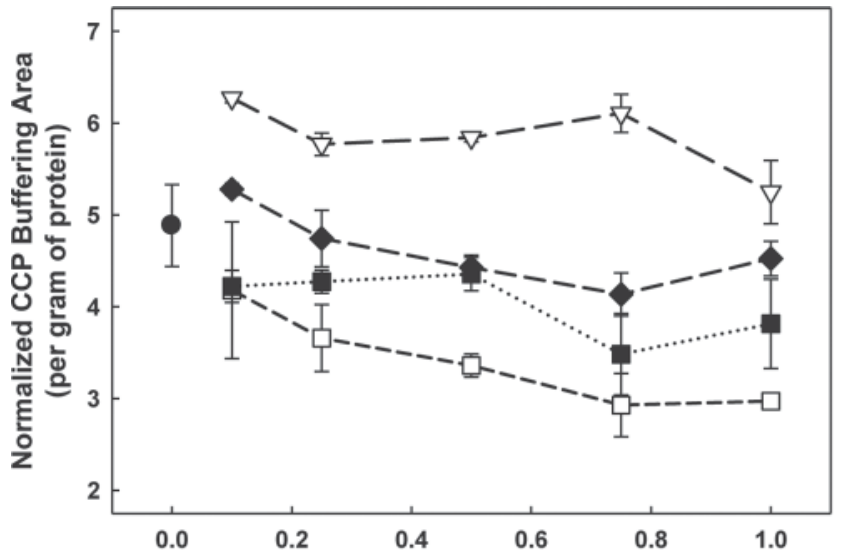

Concentration of Hofmeister Salt Added to SCCAP Solution (M)

Figure 3. Normalized buffering capacity from acid-base buffering titrations of nonfat cheese slices after incubation for $6 \mathrm{~h}$ at $22^{\circ} \mathrm{C}$ in $10 \%$ $\mathrm{NaCl}$ synthetic Cheddar cheese aqueous phase (SCCAP) solutions: control cheese $(\bullet)$, or cheese incubated in different concentrations of $\mathrm{Cl}^{-}(\nabla), \mathrm{SCN}^{-}(\bullet), \mathrm{SO}_{4}{ }^{2-}(\mathbf{\square})$, or an SCCAP solution containing $3 \%$ $\mathrm{NaCl}$ and varying concentrations of $\mathrm{SO}_{4}{ }^{2-}(\square)$. Error bars indicate \pm 1 standard deviation $(\mathrm{n}=3)$. Buffer capacity was estimated as the area between the acid and base titrations in the $\mathrm{pH}$ range 4.1 to 5.2 . CCP $=$ colloidal calcium phosphate.

$(<0.2 \mathrm{M})$, an electrostatic screening effect should be observed (von Hippel and Wong, 1964; Damodaran and Kinsella, 1982). At high HS concentrations $(>0.2 M)$, a concomitant increase occurred in the kosmo- or chaotropic effects of the HS on the cheese protein network. Salt-specific trends were observed for the compositional (Figure 1), rheological (Figure 4), and textural (Figure 5) properties of cheese at low or high concentration of HS.

\section{Thiocyanate (SCN)}

Chaotropic salts decrease the hydrophobic driving force for protein folding and decrease surface tension (by exposing hydrophobic residues) due to the increase in the number of salt molecules (decrease in water molecules) at the surface of the protein (Zhang and Cremer, 2010). A common effect of $\mathrm{SCN}^{-}$, a chaotropic HS, is increased protein solubility or swelling due to decreased hydrophobic interactions at the protein surface (Arntfield et al., 1990). Protein swelling can also be caused by the movement of $\mathrm{Na}^{+}$and $\mathrm{Cl}^{-}$ions from the cheese matrix into the brine, if the brine has a low $\mathrm{Ca}^{2+}$ concentration (Geurts et al., 1972). Lowering the concentration of $\mathrm{Na}^{+}$or $\mathrm{Cl}^{-}$salts in a brine solution also leads to the depletion of the serum-phase $\mathrm{Na}^{+}$and $\mathrm{Cl}^{-}$in the cheese, resulting in swelling of the cheese matrix (Geurts et al., 1972; Guinee, 2004). Calcium and sodium contents did not change, whereas sulfur content increased in cheeses incubated in buffers with
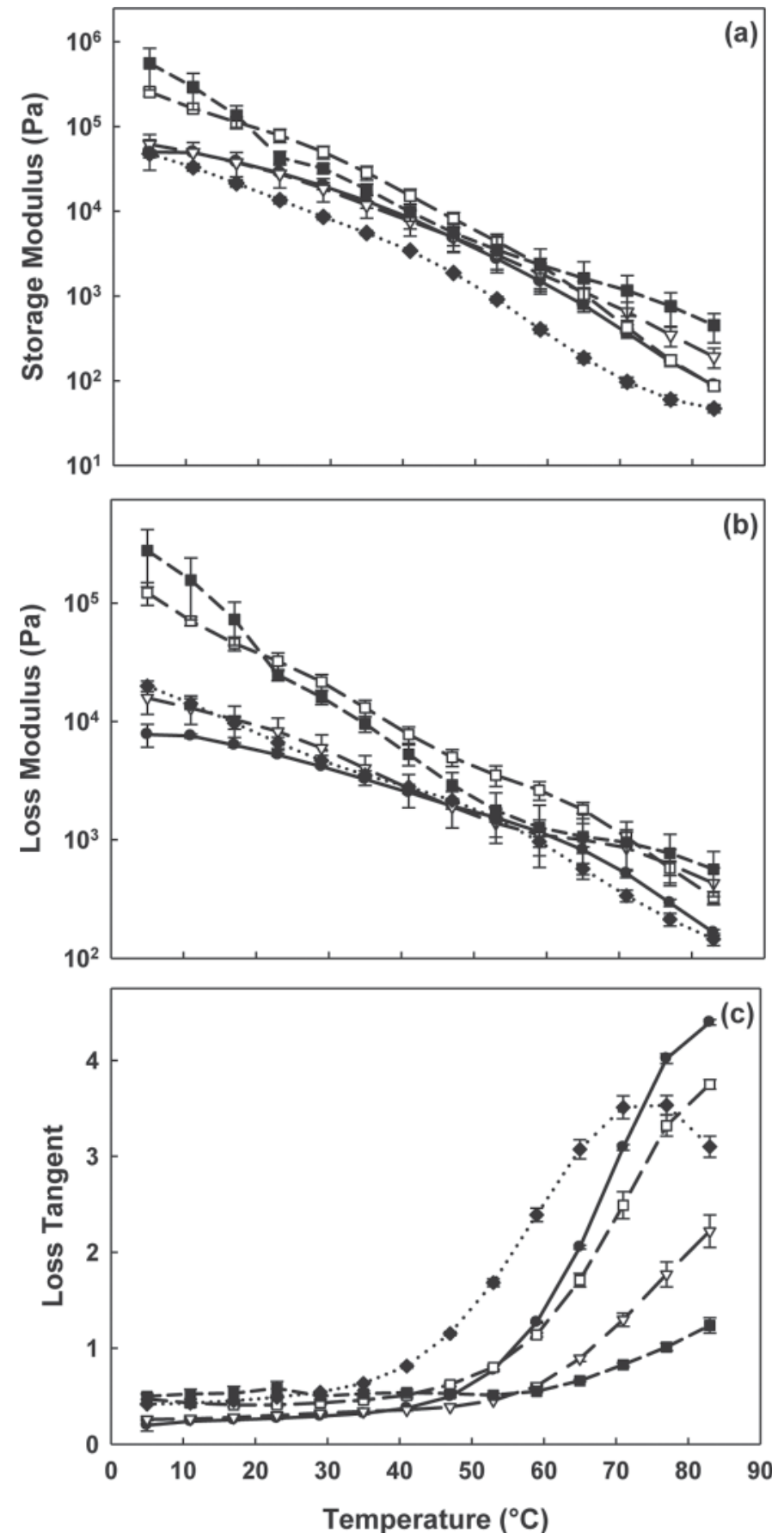

Figure 4. Storage modulus (a), loss modulus (b), and loss tangent (c) as a function of temperature of nonfat cheese slices after incubation for $6 \mathrm{~h}$ at $22^{\circ} \mathrm{C}$ in $10 \% \mathrm{NaCl}$ synthetic Cheddar cheese aqueous phase (SCCAP) solutions: control cheese $(\bullet)$, or cheese incubated in different concentrations of $\mathrm{Cl}^{-}(\nabla), \mathrm{SCN}^{-}(\bullet), \mathrm{SO}_{4}{ }^{2-}(\boldsymbol{\square})$, or an SCCAP solution containing $3 \% \mathrm{NaCl}$ and varying concentrations of $\mathrm{SO}_{4}{ }^{2-}(\square)$. Cheeses were heated from 5 to $85^{\circ} \mathrm{C}$ at a rate of $1^{\circ} \mathrm{C} / \mathrm{min}$ and a frequency of $0.1 \mathrm{~Hz}$. Error bars indicate \pm 1 standard deviation $(\mathrm{n}=3)$. 


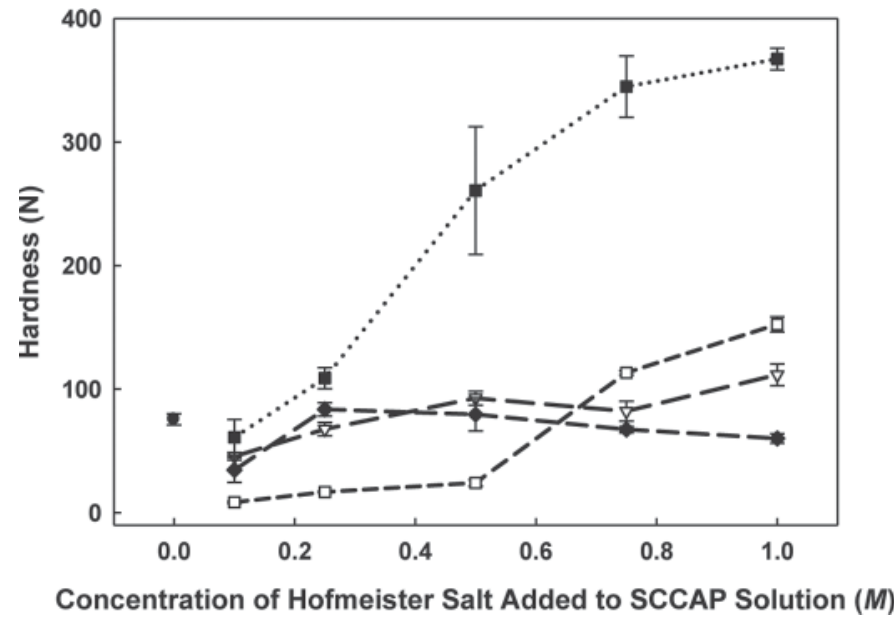

Figure 5. Hardness from texture profile analysis of nonfat cheese slices after incubation for $6 \mathrm{~h}$ at $22^{\circ} \mathrm{C}$ in $10 \% \mathrm{NaCl}$ synthetic Cheddar cheese aqueous phase (SCCAP) solutions: control cheese $(\bullet)$, or cheese incubated in different concentrations of $\mathrm{Cl}^{-}(\nabla), \mathrm{SCN}^{-}(\bullet), \mathrm{SO}_{4}{ }^{2-}(\boldsymbol{\square})$, or an SCCAP solution containing $3 \% \mathrm{NaCl}$ and varying concentrations of $\mathrm{SO}_{4}{ }^{2-}(\square)$. Error bars indicate \pm 1 standard deviation $(\mathrm{n}=3)$.

high concentrations of $\mathrm{SCN}^{-}$(Figure 1d-f). A corresponding decrease occurred in sulfur in the SCCAP buffers (results not shown). During the incubation of slices in SCCAP solutions containing $\mathrm{SCN}^{-}$, the ion diffused into the moisture phase of the NF cheese as the sulfur content increased (Figure 1f).

Arntfield et al. (1990) reported that the association of $\mathrm{SCN}^{-}$to protein molecules results in a net-negative charge on the protein, which destabilizes (weakens) the network. On a molecular level, chaotropic salts allow the buried hydrophobic residues to be exposed, resulting in the loss or disruption of the native (folded) structure of protein (Lawal, 2006). For globular proteins, chaotropic salts induce denaturation (exposure of buried hydrophobic groups) but because CN micelles do not have highly ordered secondary structures, the term denaturation may not be very appropriate.

Thermal denaturation temperature $\left(\mathbf{T}_{\mathbf{d}}\right)$ of protein is related to the thermal energy required to exceed the hydrophobic (entropic) driving force for folding. Various studies have reported that $\mathrm{SCN}^{-}$decreases the $\mathrm{T}_{\mathrm{d}}$ of globular proteins (von Hippel and Wong, 1964; Babajimopoulos et al., 1983; Arntfield et al., 1990; Wang and Damodaran, 1991). von Hippel and Wong (1964) reported that $\mathrm{SCN}^{-}$decreased the melting temperature for the helix to coil transition of ribonuclease. The Melt ${ }_{\mathrm{T}}$ of cheese is related to the amount of thermal energy needed to overcome the attractive interactions responsible for the elasticity of the matrix. We believe that $\mathrm{SCN}^{-}$could cause a decrease in $\mathrm{T}_{\mathrm{d}}$ and lower Melt $\mathrm{T}_{\mathrm{T}}$ for protein gels, as both properties are related to a weakening of hydrophobic interactions that contribute to the structure/integrity of the protein structure. A weakening of the $\mathrm{CN}-\mathrm{CN}$ interactions in cheeses incubated in high concentrations of $\mathrm{SCN}^{-}$was demonstrated by the decreased hardness (Figure 5), as well as high LT values at $70^{\circ} \mathrm{C}$ (Table 1). Arntfield et al. (1990) also found that $\mathrm{SCN}^{-}$resulted in heat-induced gels with high LT values. Cheeses incubated in $1.0 \mathrm{M} \mathrm{SCN}^{-} \mathrm{SCCAP}$ solutions had significantly lower Melt $_{\mathrm{T}}$ than the control, 1.0 $\mathrm{M} \mathrm{Cl}^{-}$, or $\mathrm{SO}_{4}{ }^{2-}$ (3 and $10 \% \mathrm{NaCl}$ solutions).

Chaotropes (i.e., $\mathrm{SCN}^{-}$) decrease hydrophobic interactions within the protein network by perturbing the first layer of water surrounding the proteins (Lawal, 2006; Zhang and Cremer, 2006), thus weakening hydrophobic interactions between CN. Rheological profiles (Figure 4) support this suggestion because cheeses incubated in 1.0 $\mathrm{M} \mathrm{SCN}^{-}$had lower $\mathrm{G}^{\prime}$ values than the control, 1.0 $M \mathrm{Cl}^{-}$, or $\mathrm{SO}_{4}{ }^{2-}(3$ and $10 \% \mathrm{NaCl})$-incubated cheeses over the temperature range $\left(10-85^{\circ} \mathrm{C}\right)$ despite having significantly lower moisture content than the control (Figure 1a). Sanchez and Burgos (1997) reported that heat-induced gels made from hydrolyzed sunflower protein isolates had a decrease in $\mathrm{G}^{\prime}$ values with the addition of high concentrations of $\mathrm{SCN}^{-}$.

The 1.0 $\mathrm{M} \mathrm{SCN}^{-}$was the only treatment that exhibited an $\mathrm{LT}_{\max }\left(\right.$ at $\sim 70^{\circ} \mathrm{C}$ ) over the temperature range 5 to $85^{\circ} \mathrm{C}$ (Figure 4c). Hydrophobic interactions increase up to a maximum at about 60 to $70^{\circ} \mathrm{C}$, at which point their strength begins to diminish (Lucey et al., 2003). The presence of an $\mathrm{LT}_{\max }$ could indicate a weakening in the strength of the hydrophobic interactions between CN particles (Figure 4c), which could have also contributed to the low $\mathrm{G}^{\prime}$ values observed at $>60^{\circ} \mathrm{C}$ (Figure 4a).

The increase in LT values at temperatures $>40^{\circ} \mathrm{C}$ occurred sooner (i.e., at a lower temperature) in cheese incubated in $1.0 \mathrm{M} \mathrm{SCN}^{-}$than in other treatments (Figure 4c). Arntfield et al. (1990) reported that the addition of $0.5 M$ NaSCN to ovalbumin and vicilin greatly decreased the $\mathrm{T}_{\mathrm{d}}$ compared with the addition of $0.5 \mathrm{M} \mathrm{Na}_{2} \mathrm{SO}_{4}$.

The microstructure of protein gels is also altered by the use of high concentrations of $\mathrm{SCN}^{-}$(Arntfield et al., 1990; Bowland and Foegeding, 1995). The addition of high levels of $\mathrm{SCN}^{-}$modified our cheese properties as it was visually obvious that the cheese became very pliable. The physical structure of the cheeses incubated in 1.0 $\mathrm{M} \mathrm{SCN}^{-}$SCCAP solutions demonstrated decreased hardness at low $\left(4^{\circ} \mathrm{C}\right)$ temperatures (Figure 5) and at high temperatures $\left(10\right.$ to $85^{\circ} \mathrm{C}$ ) low $\mathrm{G}^{\prime}$ values (Figure 4a) were observed indicative of a decrease in hydrophobic interactions between CN (Lucey et al., 2003).

Cheeses incubated in SCCAP solutions with high $(>0.8 \mathrm{M})$ concentrations of $\mathrm{SCN}^{-}$demonstrate similar effects (weakening of the protein matrix, swelling, loss 
of structure, and low temperature softening) to those previously been reported in various globular protein gel systems. We propose that during the incubation of cheese in high concentrations of $\mathrm{SCN}^{-}$, the $\mathrm{SCN}^{-}$diffuses into the serum phase of the NF cheese. At such high HS concentrations, the $\mathrm{SCN}^{-}$ions interact with each other (rather than with water molecules) and remove the monolayer water near the surface of $\mathrm{CN}$ that are in the vicinity of the serum. The removal of surface water allows a decrease in hydrophobic interactions between $\mathrm{CN}$, which disrupts the hydrophobic interactions that are one of the key crosslinking agents for CN molecules (Horne, 1998). The decreased hydrophobic interactions between $\mathrm{CN}$ are responsible for the softer, more easily meltable network observed for cheeses treated with $\mathrm{SCN}^{-}$.

Calcium, because it is involved in CCP crosslinks, plays a key role in the $\mathrm{CN}$ network of cheese (Lucey and Fox, 1993; Lucey et al., 2003). Solubilization of Ca from the cheese network results in the swelling of the para-casein matrix (Geurts et al., 1972). O'Mahony et al. (2006) found an inverse relationship between CCP concentration and moisture content (i.e., a decrease in moisture content in cheeses with high $\mathrm{Ca}$ buffers that increased the CCP concentration of the incubated cheese). Incubated cheese slices decreased in moisture content with increasing HS in the buffers (Figure 1a), yet total calcium content did not vary with increasing HS concentration (Figure 1d). The total sulfur content of the cheeses increased with increasing concentration of $\mathrm{SCN}^{-}$(Figure 1f), indicating that the HS had diffused into the moisture phase of cheese slices. The shape of the buffering curve of the $1.0 \mathrm{M} \mathrm{SCN}^{-}$cheeses (Figure 3c) was similar to that of the control (Figure 3a); likewise, the normalized buffering area was not significantly different from that of the control (Figure 2 ). The buffering results suggest that $\mathrm{SCN}^{-}$had little effect on the CCP content in our cheese.

\section{Sulfate $\left(\mathrm{SO}_{4}{ }^{2-}\right)$}

High concentrations of $\mathrm{SO}_{4}{ }^{2-}$ in the SCCAP buffer with $10 \% \mathrm{NaCl}$ resulted in cheeses with very low moisture content ("salting out"; Figure 1a) and these cheeses had greatly increased hardness (Figure 5). Sulfate salts, such as $\left(\mathrm{NH}_{4}\right)_{2} \mathrm{SO}_{4}$, are often used to salt out proteins and sulfate has historically been used to precipitate CN from solutions (Zittle, 1966). Composition and textural analysis for this cheese were difficult due to its variable composition (Figure 1d-f; Figure 5). Arntfield et al. (1990) reported that the addition of $0.5 \mathrm{M} \mathrm{SO}_{4}{ }^{2-}$ to ovalbumin resulted in protein aggregation, possibly due to enhanced hydrophobic interactions. Decreasing the $\mathrm{NaCl}$ concentration from 10 to $3 \%$ in the $\mathrm{SO}_{4}{ }^{2-} \mathrm{SC}-$
CAP buffer increased the moisture content for the 1.0 $\mathrm{M} \mathrm{SO}_{4}{ }^{2-}$ cheeses and allowed for comparison with other HS treatments with similar moisture contents (Figure 1a). Geurts et al. (1974) reported that the use of lower $\mathrm{NaCl}$ content brines resulted in cheeses with increased moisture contents.

On formulating the $1.0 \mathrm{M} \mathrm{SO}_{4}{ }^{2-}(10 \% \mathrm{NaCl}) \mathrm{SCCAP}$ solutions, it was noted that it was not possible to exceed a $\mathrm{Na}_{2} \mathrm{SO}_{4}$ concentration of $1.0 \mathrm{M}$, as precipitation of the buffer rapidly occurred. After incubation (6 h) of cheeses in the $1.0 \mathrm{M} \mathrm{SO}_{4}{ }^{2-}(10 \% \mathrm{NaCl})$ solutions, the buffer was cloudy and a white precipitate settled out at the bottom of the beaker after collecting the pooled buffer.

At low $\mathrm{SO}_{4}{ }^{2-}$ concentration $(<0.6 \mathrm{M})$, samples incubated in $3 \% \mathrm{NaCl}$ SCCAP solutions had very high moisture contents (Figure 1a). Visually, the cheeses lost much of their structure. Guinee and Fox (1986) reported a similar trend for Romano cheeses that were incubated in low $\mathrm{NaCl}$ brines $[6.5 \%$; i.e., moisture content increased above the control ("salting-in") due to increased protein solubility, resulting in swelling of the CN matrix]. Sodium content and swelling greatly increased when cheeses were incubated in the low $(3 \%)$ $\mathrm{NaCl}$ buffer for $\mathrm{SO}_{4}{ }^{2-}$ (Figure 1e). This was due to the removal of $\mathrm{NaCl}$ from the buffer and transfer to the cheese (Geurts et al., 1972; Geurts et al., 1974; Guinee and Fox, 1986). Geurts et al. (1972) and Monib (1962) reported swelling in cheeses and para-casein systems in the presence of low $\mathrm{NaCl}$ buffer/brine solutions. At high concentrations of $\mathrm{SO}_{4}{ }^{2-}(>0.6 \mathrm{M})$ no swelling occurred as the moisture content decreased (Figure 1a) and hardness increased (Figure 5).

The $\mathrm{pH}$ increase in $\mathrm{SO}_{4}{ }^{2-}$ cheeses incubated in $3 \%$ $\mathrm{NaCl}$ SCCAP buffers was probably due to the replacement of $\mathrm{Na}^{+}$for $\mathrm{H}^{+}$in the cheese. Additional textural tests were performed on cheeses incubated in $1.0 \mathrm{M}$ $\mathrm{SO}_{4}{ }^{2-}$ SCCAP solutions where the $\mathrm{pH}$ was adjusted (i.e., to become similar to the other treatments). The texture tests were of cheeses with the modified $\mathrm{pH}$ was similar to those with the unmodified $\mathrm{pH}$ (results not shown). Changes in the acid-base buffering curves for cheeses incubated in $1.0 \mathrm{M} \mathrm{SO}_{4}{ }^{2-}(3$ and $10 \% \mathrm{NaCl}$ solutions; Figure 2d,e) may be related to $\mathrm{Na}^{+}$and $\mathrm{H}^{+}$ ion exchange in the native CCP.

At low temperatures, $\left(5^{\circ} \mathrm{C}\right)$ the $\mathrm{G}^{\prime \prime}$ and $\mathrm{G}^{\prime}$ values for cheeses incubated in $1.0 \mathrm{M} \mathrm{SO}_{4}{ }^{2-}(3 \% \mathrm{NaCl})$ were significantly higher than other treatments (Table 1; Figure $4 \mathrm{a}, \mathrm{b})$. Some studies on the formation of heatinduced gels from globular proteins have reported that high $\mathrm{SO}_{4}{ }^{2-}$ concentrations produce weak gels (Babajimopoulos et al., 1983; Arntfield et al., 1990; Sanchez and Burgos, 1997). The addition of $\mathrm{SO}_{4}{ }^{2-}$ increases the $T_{d}$ of globular proteins due to the enhancement 
of hydrophobic interactions; thus, higher temperatures are required to overcome the hydrophobic interactions that stabilize the protein structure (von Hippel and Wong, 1964; Babajimopoulos et al., 1983; Arntfield et al., 1990). The formation of heat-induced gels from globular protein requires that the protein is first denatured and then the unfolded proteins can aggregate by various interactions, including hydrophobic interactions. Thus, the addition of $\mathrm{SO}_{4}{ }^{2-}$ increases the $\mathrm{T}_{\mathrm{d}}$, which could inhibit the initial denaturation step but enhances hydrophobic interactions that could increase the strength of the heat-induced gel. Several studies have indicated that the addition of $\mathrm{SO}_{4}{ }^{2-}$ enhanced the strength (O'Riordan et al., 1989) or elasticity (Mulvihill et al., 1990) of heat-induced gels. Very high levels of $\mathrm{SO}_{4}{ }^{2-}$ result in salting out of proteins and this prevents heat-induced gelation.

Our study involved the addition of HS to an existing gel network (cheese), which is a very different situation to that in previous studies on the solubility of protein solutions or heat-induced protein gelation. Due to numerous interactions that contribute to the structure of the cheese matrix, the addition of $\mathrm{SO}_{4}{ }^{2-}$ to the buffer did not precipitate $\mathrm{CN}$, rather the $\mathrm{SO}_{4}{ }^{2-}$ ions may have increased hydrophobic interactions between $\mathrm{CN}$, resulting in the loss of water and a localized rearrangement of the $\mathrm{CN}$ in the matrix (as we observed visible changes in the appearance of the cheese). Previous studies have indicated that the addition of high concentrations of $\mathrm{SO}_{4}{ }^{2-}$ during the formation of heat-induced protein gels altered the microstructure (Arntfield et al., 1990; Bowland and Foegeding, 1995).

Texture analysis results (Figure 5) agreed with these rheological trends (Figure 4); at low temperatures $\left(5^{\circ} \mathrm{C}\right)$, samples incubated in $1.0 \mathrm{M} \mathrm{SO}_{4}{ }^{2-}(3 \% \mathrm{NaCl}$ solutions) had significantly higher hardness values than other treatments (Figure 5). Hydrophobic interactions in cheese are weak at low temperatures (Lucey et al., 2003). The moisture content for $\mathrm{SO}_{4}{ }^{2-}(3 \% \mathrm{NaCl}$ solution) was significantly lower than the control (Figure 1a), but did not differ significantly from the $\mathrm{SCN}^{-}$or $\mathrm{Cl}^{-}$treatment, indicating that this type of HS still affects the cheese network even when hydrophobic interactions were weak. At low temperatures, other forces (i.e., electrostatic interactions or CCP crosslinks) are still present in the CN network (Horne, 1998; Lucey et al., 2003) and appear to be modified by the presence of $\mathrm{HS}$, as hardness followed the trend: $\mathrm{SO}_{4}{ }^{2-}>$ $\mathrm{Cl}^{-}>\mathrm{SCN}^{-}$(Figure 5). Because $\mathrm{SO}_{4}{ }^{2-}$ was added in the form $\mathrm{Na}_{2} \mathrm{SO}_{4}$, compared with the other HS, which were monovalent HS, the ionic strength was higher for $\mathrm{SO}_{4}{ }^{2-}$ buffers.

The Melt ${ }_{\mathrm{T}}$ for the $\mathrm{SO}_{4}{ }^{2-}(3 \% \mathrm{NaCl}$ solution $)$ did not differ significantly from the control, yet the $\mathrm{LT}_{85}$ value was lower than that of the control, indicating that at higher temperatures this cheese did not soften as much as the control (Table 1; Figure 4c). During heating, the increased strength in hydrophobic interactions typically reduces the contact between $\mathrm{CN}$ molecules, which reduces overall gel strength (Lucey et al., 2003). It is possible that $\mathrm{SO}_{4}{ }^{2-}$ enhanced the hydrophobic interactions within the $\mathrm{CN}$ network and helped maintain gel stiffness during the heating step.

We propose that the use of high concentrations of $\mathrm{SO}_{4}{ }^{2-}$ results in the sulfate ions diffusing into the moisture phase of $\mathrm{NF}$ cheese. Once incorporated into the matrix, the $\mathrm{SO}_{4}{ }^{2-}$ ions prefer to interact with other $\mathrm{SO}_{4}{ }^{2-}$ ions, which forces water molecules to the $\mathrm{CN}$ surface. This causes an enhancement of hydrophobic interactions between $\mathrm{CN}$ that is responsible for the increased hardness (Figure 5) and stiffness during the heating process (Figure 4). The high Melt $_{\mathrm{T}}$ for cheese with $\mathrm{SO}_{4}{ }^{2-}$ (Table 1) is similar to the increased $\mathrm{T}_{\mathrm{d}}$, reported for proteins (von Hippel and Wong, 1964). Very high $\mathrm{SO}_{4}{ }^{2-}$ levels resulted in considerable moisture loss from cheese, which is a form of salting out of the CN system.

\section{Chloride (CГ)}

Within the HS series, $\mathrm{Cl}^{-}$is classified as a weak kosmotrope (Kunz, 2010). This description appeared to be accurate for the NF cheese system. The relationship between $\mathrm{NaCl}$ and cheese has been thoroughly investigated (see the review by Guinee and Fox, 2004). Geurts et al. (1974) modeled the transport of $\mathrm{NaCl}$ into cheese during the brining of Gouda cheese; they calculated the rate of diffusion of $\mathrm{NaCl}$ was approximately $2 \mathrm{~mm}^{2} / \mathrm{d}$. After the 6-h incubation period, cheeses were stored for another $18 \mathrm{~h}$, which should have allowed the ions sufficient time to reach equilibrium, as the thickness of the cheese slices was $2 \mathrm{~mm}$.

Increasing the concentration of $\mathrm{Cl}^{-}$in the SCCAP solution resulted in cheeses with a decrease in moisture content and increased protein content (Figure 1a,c). These results are in agreement with those of Geurts et al. (1980) who reported that $\mathrm{NaCl}$ uptake in cheese increased with an increase in the concentration of $\mathrm{NaCl}$ in the brine. The water lost (lower final moisture content) is greater than the $\mathrm{NaCl}$ gained due to the difference in the molecular size of $\mathrm{H}_{2} \mathrm{O}$ compared with $\mathrm{Na}^{+}$ and $\mathrm{Cl}^{-}$ions (Guinee and Fox, 1986).

The hardness of globular protein gels increases with an increase in the concentrations of $\mathrm{Cl}^{-}$(Arntfield et al., 1990; Mulvihill et al., 1990; Wang and Damodaran, 1991), which is in agreement with the increased hardness of cheeses with increasing $\mathrm{Cl}^{-}$concentration (Figure 5). The $\mathrm{G}^{\prime}$ and $\mathrm{G}^{\prime \prime}$ values over the temperature 
range from 5 to $85^{\circ} \mathrm{C}$ for cheeses incubated in $1.0 \mathrm{M} \mathrm{Cl}^{-}$ (Figure 4a,b) decreased less than in other treatments, which indicates that $\mathrm{Cl}^{-}$cheeses do not soften as much with increasing temperature. The Melt ${ }_{\mathrm{T}}$ for $1.0 \mathrm{M} \mathrm{Cl}^{-}$ cheeses was much higher than that in the control and 1.0 $M \mathrm{SCN}^{-}$treatments. At high $\mathrm{NaCl}$ levels, greatly increased electrostatic screening of charges occurred between CN, which should enhance hydrophobic interactions, according to the dual-bonding $\mathrm{CN}$ approach of Horne (Horne, 1998).

\section{CONCLUSIONS}

Hofmeister salts are known to influence hydrophobic interactions in globular proteins. Although $\mathrm{CN}$ are not globular proteins, hydrophobic interactions do play a major role in the formation of $\mathrm{CN}$ micelles and greatly influence the properties of CN-based networks, such as cheese. Salts from the HS influence the hydrophobic interactions within protein networks: increasing (kosmotropes; i.e., $\mathrm{SO}_{4}{ }^{2-}$ ) or decreasing (chaotropes; i.e., $\mathrm{SCN}^{-}$) hydrophobic interactions. The HS effect was concentration dependent. At low HS concentrations (e.g., $0.1 \mathrm{M}$ ), electrostatic interactions were weakened but the cheese matrix remained intact due to the presence of other (non-electrostatic) types of interactions (e.g., CCP crosslinks, hydrophobic interactions). The HS influence on hydrophobic interactions became species dependent as the concentration approached 1.0 M. The strength of the NF cheeses matrix incubated in $1.0 \mathrm{M}$ of different types of HS increased in the order $\mathrm{SO}_{4}{ }^{2-}>\mathrm{Cl}^{-}>\mathrm{SCN}^{-}$, which was similar to the effect of these salts on decreasing hydrophobic interactions. The results of this study are consistent with the view that the main $\mathrm{CN}$ interactions in cheese are hydrophobic and electrostatic interactions, as well as CCP crosslinks. These results provide a better understanding of the role of hydrophobic interactions in $\mathrm{CN}$ networks, which might assist in improving NF cheese texture.

\section{ACKNOWLEDGMENTS}

The authors gratefully acknowledge the financial support of this research by the Dairy Research Institute (Rosemont, IL).

\section{REFERENCES}

Arntfield, S. D., E. D. Murray, and M. A. H. Ismond. 1990. Influence of salts on the microstructural and rheological properties of heatinduced protein networks from ovalbumin and vicilin. J. Agric. Food Chem. 38:1335-1343.

Babajimopoulos, M., S. Damodaran, S. S. H. Rizvi, and J. E. Kinsella. 1983. Effects of various anions on the rheological and gelling behavior of soy proteins: Thermodynamic observations. J. Agric. Food Chem. 31:1270-1275.
Banks, J. M. 2004. The technology of low-fat cheese manufacture. Int. J. Dairy Technol. 57:199-207.

Bourne, M. C. 1978. Texture profile analysis. Food Technol. 32:6266,72 .

Bowland, E. L., and E. A. Foegeding. 1995. Effects of anions on thermally induced whey protein isolate gels. Food Hydrocoll. 9:47-56.

Brickley, C. A., S. Govindasamy-Lucey, J. J. Jaeggi, M. E. Johnson, P. L. H. McSweeney, and J. A. Lucey. 2008. Influence of emulsifying salts on the textural properties of nonfat process cheese made from direct acid cheese bases. J. Dairy Sci. 91:39-48.

Broome, M. C., and G. K. Y. Limsowtin. 2002. Development of a cheese aqueous phase model. Aust. J. Dairy Technol. 57:118.

Damodaran, S., and J. E. Kinsella. 1982. Effects of ions on protein conformation and functionality. Pages 327-357 in Food Protein Deterioration: Mechanisms and Functionality. J. P. Cherry, ed. Am. Chem. Soc. Symp. Ser. 206. Am. Chem. Soc., Washington, DC.

ERS (Economic Research Service) and USDA. 2010. Food availability (per capita) data system. Accessed May 11, 2010. http://www.ers. usda.gov/Data/FoodConsumption.

Geurts, T. J., P. Walstra, and H. Mulder. 1972. Brine composition and the prevention of the defect 'soft rind' in cheese. Neth. Milk Dairy J. 26:168-179.

Geurts, T. J., P. Walstra, and H. Mulder. 1974. Transport of salt and water during salting of cheese. I. Analysis of the processes involved. Neth. Milk Dairy J. 28:102-129.

Geurts, T. J., P. Walstra, and H. Mulder. 1980. Transport of salt and water during salting of cheese. 2. Quantities of salt taken up and of moisture lost. Neth. Milk Dairy J. 34:229-254.

Guinee, T. P. 2004. Salting and the role of salt in cheese. Int. J. Dairy Technol. 57:99-109.

Guinee, T. P., and P. F. Fox. 1986. Transport of sodium chloride and water in Romano cheese slices during brining. Food Chem. 19:49-64.

Guinee, T. P., and P. F. Fox. 2004. Salt in cheese: Physical, chemical and biological aspects. Pages 207-259 in Cheese: Chemistry, Physics and Microbiology. 3rd ed. Vol. 1. P. F. Fox, P. L. H. McSweeney, T. M. Cogan, and T. P. Guinee, ed. Academic Press, London, UK.

Hassan, A., M. E. Johnson, and J. A. Lucey. 2004. Changes in the proportions of soluble and insoluble calcium during the ripening of Cheddar cheese. J. Dairy Sci. 87:854-862.

Horne, D. S. 1998. Casein Interactions: Casting light on the black boxes, the structure in dairy products. Int. Dairy J. 8:171-177.

IDF. 1982. Cheese and processed cheese. Determination of the total solids content. 4A:1982. International Dairy Federation, Brussels, Belgium.

IDF. 1986. Determination of nitrogen content (Kjeldahl method) and calculation of crude protein content. 20A:1986. International Dairy Federation, Brussels, Belgium.

Kunz, W. 2010. Specific ion effects in colloidal and biological systems. Curr. Opin. Colloid Interface Sci. 15:34-39.

Kunz, W., P. Lo Nostro, and B. W. Ninham. 2004. The present state of affairs with Hofmeister effects. Curr. Opin. Colloid Interface Sci. 9:1-18.

Lawal, O. S. 2006. Kosmotropes and chaotropes as they affect functionality of a protein isolate. Food Chem. 95:101-107.

Lucey, J. A., and P. F. Fox. 1993. Importance of calcium and phosphate in cheese manufacture: A review. J. Dairy Sci. 76:1714-1724.

Lucey, J. A., M. E. Johnson, and D. S. Horne. 2003. Perspectives on the basis of the rheology and texture properties of cheese. J. Dairy Sci. 86:2725-2743.

Marshall, R. T. 1992. Standard Methods for the Examination of Dairy Products. 16th ed. American Public Health Association, Washington, DC.

Monib, A. M. M. F. 1962. The calcium-paracaseinate-phosphate complex under conditions similar to those in cheese. Meded. Landbouwhogesch. Wageningen 62:1-76.

Morris, H. A., C. Holt, B. E. Brooker, J. M. Banks, and W. Manson. 1988. Inorganic constituents of cheese: Analysis of juice from one-month-old Cheddar cheese and the use of light and electron 
microscopy to characterize the crystalline phases. J. Dairy Res. $55: 255-268$.

Mulvihill, D. M., D. Rector, and J. E. Kinsella. 1990. Effects of structuring and destructuring anionic ions on the rheological properties of thermally induced $\beta$-lactoglobulin gels. Food Hydrocoll. $4: 267-276$

O’Mahony, J. A., P. L. H. McSweeney, and J. A. Lucey. 2006. A model system for studying the effects of colloidal calcium phosphate concentration on the rheological properties of Cheddar cheese. J. Dairy Sci. 89:892-904.

O'Riordan, D., P. A. Morrissey, J. E. Kinsella, and D. M. Mulvihill 1989. The effects of salts on the rheological properties of plasma protein gels. Food Chem. 34:249-259.

Park, Y. W. 2000. Comparison of mineral and cholesterol composition of different commercial goat milk products manufactured in USA. Small Rumin. Res. 37:115-124.

Resch, J. J., C. R. Daubert, and E. A. Foegeding. 2005. The effects of acidulant type on the rheological properties of beta-lactoglobulin gels and powders derived from these gels. Food Hydrocoll. 19:851-860.

Sanchez, A. C., and J. Burgos. 1997. Factors affecting the gelation properties of hydrolyzed sunflower proteins. J. Food Sci. 62:284288
Sutheerawattananonda, M., and E. D. Bastian. 1998. Monitoring process cheese meltability using dynamic oscillatory rheometry. J. Texture Stud. 29:169-183.

Udayarajan, C. T., J. A. Lucey, and D. S. Horne. 2005. Use of Fourier transform mechanical spectroscopy to study the melting behavior of cheese. J. Texture Stud. 36:489-515.

von Hippel, P. H., and K.-Y. Wong. 1964. Neutral salts: The generality of their effects on the stability of macromolecular conformations. Science 145:577-580.

Wang, C. H., and S. Damodaran. 1991. Thermal gelation of globular proteins: Influence of protein conformation on gel strength. J. Agric. Food Chem. 99:433-438.

Zhang, Y., and P. S. Cremer. 2006. Interactions between macromolecules and ions: The Hofmeister series. Curr. Opin. Chem. Biol. 10:658-663.

Zhang, Y., and P. S. Cremer. 2010. Chemistry of Hofmeister anions and osmolytes. Annu. Rev. Phys. Chem. 61:63-83.

Zittle, C. A. 1966. Precipitation of casein from acidic solutions by divalent anions. J. Dairy Sci. 4:361-364. 